\title{
Correlates of Pollution Load and Assessment of Water Quality Index of a Major Stream along Yemetu Community in Ibadan Nigeria
}

\author{
Oluwatosin E. Amubieya, Elizabeth O. Oloruntoba*, Mumuni Adejumo, Mynepalli K.C. Sridhar \\ Department of Environmental Health Sciences, Faculty of Public Health, College of Medicine University of Ibadan, Ibadan \\ 200212, Nigeria
}

Corresponding Author Email: eoloruntoba@com.ui.edu.ng

https://doi.org/10.18280/eesrj.070102

Received: 22 December 2019

Accepted: 27 January 2020

\section{Keywords:}

water quality, correlation, Yemetu stream, pollution, sampling points, water quality index, physico-chemical parameters

\begin{abstract}
This study aimed at assessing the correlates of pollution loads and water quality index of a major stream along Yemetu community in Ibadan, Nigeria. Water samples were collected during the raining season at eight sampling points (S1 to S8) for four weeks for physicochemical and bacteriological analyses using standard methods described by American Public Health Association (APHA) (2005). Pearson correlation coefficient was used to identify correlated parameters and Water Quality Index (WQI) was used to classify the quality of the water. The $\mathrm{pH}$ at all sampling points were slightly acidic, Total coliforms and $E$. coli counts were higher than the permissible limits, BOD 5 was significantly correlated with COD $(\mathrm{r}=0.97, \mathrm{P}<0.01)$, EC $(\mathrm{r}=0.71, \mathrm{P}<0.05)$, TDS $(\mathrm{r}=$ $0.75, \mathrm{P}<0.05)$, TCC $(\mathrm{r}=0.89, \mathrm{P}<0.05)$, and $E$. coli $(\mathrm{r}=0.86, \mathrm{P}<0.05)$. The WQI ranged from 227 (very poor water) in S1 to 667 (water unsuitable for drinking) in S7. The study recommends effective monitoring of water quality of the stream (most especially the bacteriological characteristics) through the control of various anthropogenic activities around the stream by the appropriate authorities.
\end{abstract}

\section{INTRODUCTION}

Water according to Allan [1] is regarded as an essential resource to all forms of life. It constitutes $50-97 \%$ of the weight of all plants and animals, and about $70 \%$ of the human body. Sources of fresh water could be in the form of surface water (e.g. lakes, and rivers), glaciers, groundwater, rainwater, etc. Apart from drinking purpose, water resources play a vital role in different sectors including agriculture, forestry, livestock production, industrial activities, fisheries, hydropower generation, and other activities. The quality and availability of surface water have been impaired as a result of factors such as increasing population, industrialization and urbanization [2]. Several anthropogenic activities have resulted in a significant decrease in the quality of water in the aquatic systems [3]. Streams play a key role in receiving and dispersal of many municipal, industrial and agricultural wastewater [4]. The water pollution problem is being experienced by both developed and developing countries. Human activities bring about pollution of water by the introduction of various wastes into water bodies. Pathogenic organisms, plant nutrients that stimulate algal blooms, oxygen-demanding organic substances, inorganic, and organic toxic substances are the most common pollutants of water [5]. The quality of water in a stream can be determined through assessment of various constituents present. When water quality is poor, it affects not only the aquatic life but also the surrounding ecosystem [6]. To keep streams and aquatic systems healthy, certain water quality indicators or parameters must be examined and put to check. Water Quality Index (WQI) was used to classify the level of pollution of Yemetu stream in this study.
Water quality index is an approach that expresses the overall quality of water of a particular location at a particular time based on certain water quality parameters [7]. The development of WQI was coined by Horton in the early 1970s where a mathematical method was employed to calculate a single value from multiple test results [7]. The result of WQI gives information on the quality of water in a given water basin, such as river, lake, or stream. After Horton, several workers all over the world developed WQI based on rating of different water quality parameters [8-11]. A number of physicochemical and bacteriological parameters are required to calculate the quality index of a particular stream. Basically, WQI attempts to provide a mechanism through which a cumulatively derived numerical expression is used to define the water quality of water in a particular stream [12]. The index (WQI) summarizes large data on water quality into simple terms (such as: excellent, good, poor and unsuitable) to report to the public and appropriate stakeholders in a consistent manner [13]. It compares the quality of water of different sources and reveals the pollution level of that particular water source [14].

Streams and rivers in many urban and semi-urban areas in Nigeria are polluted due to the discharge of organic wastes and untreated wastewater directly into them [15]. Thus, making river pollution a central issue of water management in Nigeria [16]. Studies have revealed the various impact of human activities and their implications on our aquatic resources [1719]. Yemetu stream is an urban stream that receives untreated wastewater and organic wastes from the surrounding households and is also subjected to various anthropogenic impacts. This study was aimed to assess the correlates of 
pollution loads and the water quality index of a major stream along Yemetu community in Ibadan, Nigeria.

\section{MATERIALS AND METHODS}

\subsection{Study area}

This study assessed the pollution load of Yemetu stream, in Yemetu community, Ibadan North Local Government Area, Ibadan, Oyo State, South-west, Nigeria. The community was described in Oloruntoba et al. [20]. In the study area, some households along the stream discharged their excreta into the stream. Eight stations were purposively selected along the stream (Figure 1).

\subsection{Sample collection}

Water samples were collected from eight sampling stations along Yemetu stream for four weeks between September and October, 2017. It was raining season and the river flow was optimal. Separate sample containers were used to collect water samples for analysis of the physico-chemical, bacteriological parameters, and Biochemical Oxygen Demand (BOD 5$)$. Plastic kegs of 1.5 litres capacity were used to collect samples for physico-chemical analysis while samples for $\mathrm{BOD}_{5}$ analysis were collected using BOD bottles which were filled completely to expel air bubbles. Samples were collected from each of the selected sampling stations once a week for a period of 4 weeks according to the standard methods described by the American Public Health Association [21]. The sample bottles were tightly stoppered after each collection and transported to the laboratory for determination of physico-chemical parameters such as $\mathrm{pH}$, Electrical Conductivity, Total Dissolved Solids, Total Suspended Solids, Nitrate, phosphate, Dissolved Oxygen and $\mathrm{BOD}_{5}$ using standard methods [21]. Samples for bacteriological examination were collected using glass sample bottles which were pre-washed with distilled water and sterilized in an oven at $170^{\circ} \mathrm{C}$ for 1 hour. The samples were collected under aseptic conditions, stored in light-proof containers with ice packs at $4{ }^{\circ} \mathrm{C}$, and transported to the laboratory for immediate estimation of total coliform and Escherichia coli counts [21].

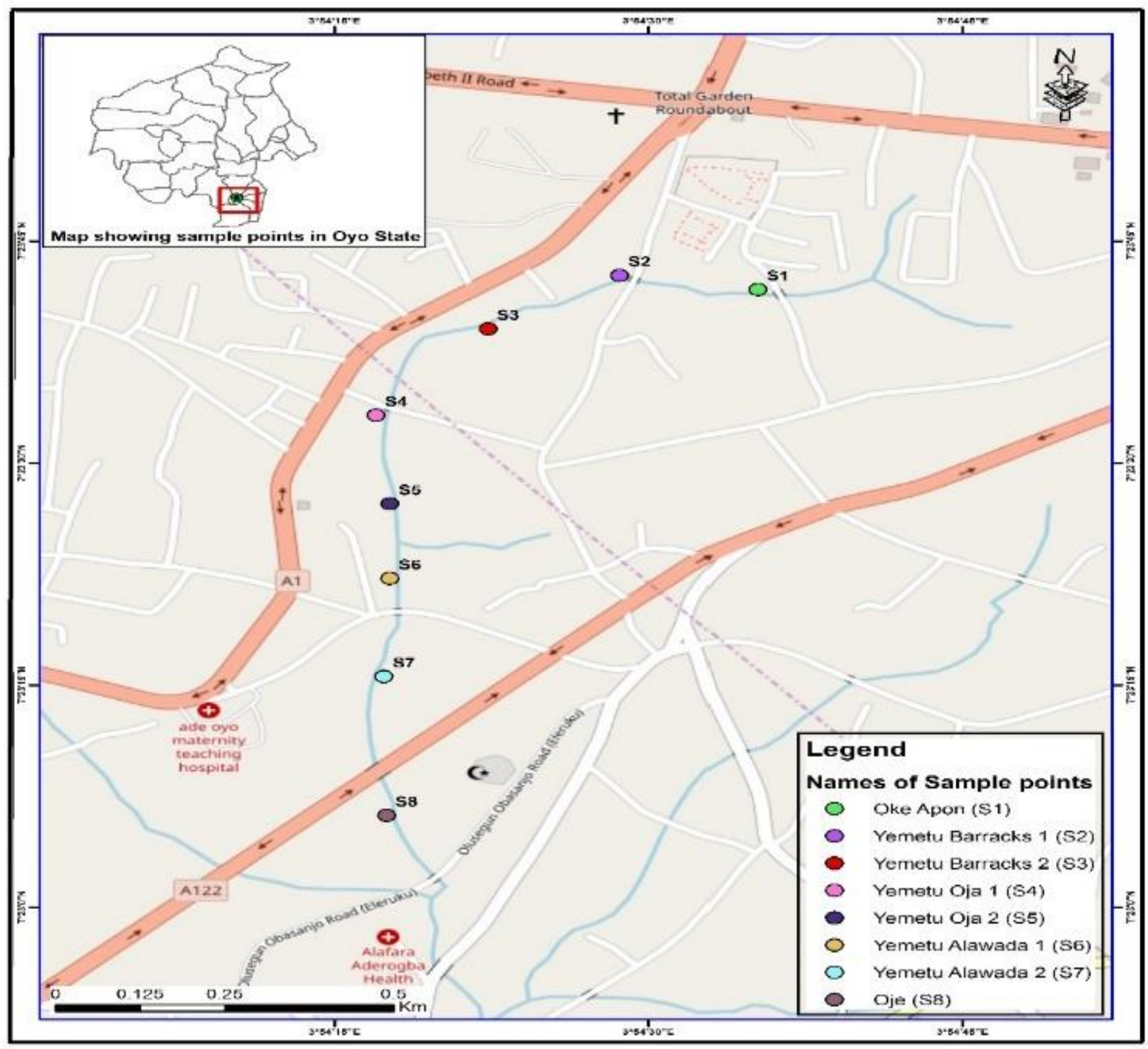

Figure 1. Map of Yemetu community showing the sampling points 
Table 1. Unit weight, relative weight and WHO/NESREA standards for WQI computation

\begin{tabular}{cccc}
\hline Parameters [Units] & Unit weight & Relative weight & WHO/NESREA Standards \\
\hline $\mathrm{pH}$ & 3 & 0.088 & $6.5-8$ \\
Conductivity $\mu \mathrm{s} / \mathrm{cm}$ & 2 & 0.059 & 400 \\
Total Dissolves Solids TDS) [mg/L] & 3 & 0.088 & 500 \\
Total Suspended Solids (TSS) [mg/L] & 3 & 0.088 & 30 \\
Dissolved Oxygen (DO) [mg/L] & 4 & 0.118 & 7.5 \\
Biochemical Oxygen Demand (BOD) [mg/L] & 5 & 0.147 & 40 \\
Chemical Oxygen Demand (COD) [mg/L] & 5 & 0.147 & 80 \\
Nitrate [mg/L] & 4 & 0.118 & 50 \\
Total Coliforms [MPN/100mL] & 5 & 0.147 & 10 \\
\hline
\end{tabular}

\subsection{Laboratory analysis}

The $\mathrm{pH}$ was determined using a pre-calibrated $\mathrm{pH}$ meter (Bosch PHS-25 CW) while EC and TDS were measured using a Jenway TDS/EC combined meter. TSS was determined using gravimetric method while dissolved oxygen was determined using the Jenway Model 9070 waterproof DO meter. The $\mathrm{BOD}_{5}$ of the water sample was determined using the Jenway Model 9070 waterproof DO meter. The $\mathrm{DO}_{1}$ was determined on the first day while the sample for $\mathrm{DO}_{5}$ was incubated at $20^{\circ} \mathrm{C}$ and determined on the fifth day. The COD was determined by a titrimetric method using Standard Methods as described by APHA [21]. Nitrate was determined using the Phenol Disulphonic Acid method while phosphate was determined using the stannous chloride method. The Total coliforms and E. coli counts were determined by standard methods described by [21]. The media used for the Total coliforms and E. coli determination were MacConkey and Brilliant green bile broth respectively. The samples were thereafter incubated for $24 \mathrm{~h}$ at $37^{\circ} \mathrm{C}$ for total coliforms and at $44^{\circ} \mathrm{C}$ for the E. coli. The Most Probable Number (MPN) technique was adopted in estimating the microbial populations. All media were prepared according to the manufacturers' specifications. All reagents used for analysis were prepared from analar grade chemicals. Appropriate reagent blanks were prepared for each analysis to ensure Quality Control and Quality Assurance. All analyses were carried out in triplicates [21].

\subsection{Calculation of water quality index}

This study adapted the Water quality index method described by Mohamad [22]. A total of nine parameters ( $\mathrm{pH}$, conductivity, total dissolved solids, total suspended solids, dissolved oxygen, Nitrate, biochemical oxygen demand, chemical oxygen demand, and Total coliform count) were used to evaluate the water quality index of the stream. Values were compared with WHO guidelines /NESREA Standards. Four steps were used to compute the WQI of the water. The four steps are:

\subsubsection{Assignment of unit weight to each parameter}

Each parameter being considered was assigned a weight (wi) based on their perceived effects and their importance to water quality (Table 1). Parameters with major effects on water quality were assigned with highest weight of 5 while those considered not harmful were assigned a minimum weight of 2 . Each parameter's relative weight $(W i)$ was computed by dividing its unit weight by the summation of all parameters using the following formula:

$$
W i=\frac{\text { wi }}{\sum_{i}^{n}=1 W i}
$$

where: $\mathrm{W} i=$ the relative weight,

$w i=$ unit weight of each parameter and

$n \mathrm{i}=$ number of selected parameters ( $n=9$ in this study)

\subsubsection{Quality rating scale calculation for each parameter}

The Each parameter's rating scale $(Q i)$ was calculated by dividing the concentration of each parameter by the value of its permissible limit as defined by WHO/NESREA and the result multiplied by 100 according to the equation below:

$$
Q i=\left(\frac{C i}{S i}\right) \times 100
$$

where:

$Q i=$ quality rating scale,

$C \mathrm{i}=$ concentration of each parameter $i n \mathrm{mg} / \mathrm{L}$

$S i=$ drinking water standard for each parameter in $\mathrm{mg} / \mathrm{L}$

\subsubsection{Calculation of sub-indices}

The determination of water quality sub-index value (SIi) was done for each parameter through the multiplication of its relative weight $(W i)$ with its quality rating scale $(Q i)$ as expressed in the equation below

$$
S l i=W i \times \mathrm{Q} i
$$

\subsubsection{Summation of sub-indices}

The addition of sub-indices of all the selected parameters was done to determine the WQI of the stream as indicated in the equation below:

$$
W Q I=\sum_{i=1}^{n} S l i
$$

The water quality of the stream was determined according to the computed WQI values obtained. The WQI was categorized into five classifications [23], as shown in Table 2.

Table 2. Water quality indices range and classification

\begin{tabular}{cc}
\hline WQI Range & Type of water \\
\hline$<50$ & Excellent water \\
$50-100$ & Good water \\
$100.1-200$ & Poor water \\
$200.1-300$ & Very poor water \\
$>300$ & Water unsuitable \\
\hline
\end{tabular}


Table 3. The classification of lakes (trophic status) on the basis of total phosphate

\begin{tabular}{ccc}
\hline S/No & Trophic status & Values of $\mathbf{P O}_{4}{ }^{2-} \mathbf{~ m g} / \mathbf{L}$ \\
\hline 1. & Oligotrophic & $<0.005$ \\
2. & Mesotrophic & $0.005-0.01$ \\
3. & Mesoeutrophic & $0.01-0.03$ \\
4. & Eutrophic & $0.03-0.1$ \\
5. & Hypereurtrophic & $>0.1$ \\
\hline
\end{tabular}

\subsection{Data management}

All results were statistically analyzed using Statistical Package for Social Sciences (SPSS) version 20. Data were analysed using descriptive statistics (the mean and standard deviation) while Pearson's correlation coefficient (r) was used to determine highly interrelated and correlated parameters. The required number of the component was determined using a screen plot and the suitability of the data for Principal Component Analysis (PCA) was evaluated by Kaiser-MeyerOlkin (KMO) and Bartlett test of sphericity. Nine parameters were used in the Cluster Analysis. The similarities between clusters and separating homogenous clusters were determined based on Euclidean distance and hierarchical Cluster Analysis using Ward's Method. The trophic state of Yemetu stream was computed with the mean phosphate concentration along the eight sampling stations which were plotted in box and whisker chart. The stream tropic status was compared with the classification of lakes (tropic status) on the basis of total phosphate described by Wetzel [24] (Table 3).

\section{RESULTS}

Characteristics of the stream at the eight sampling stations are presented in Table 4 . The $\mathrm{pH}$ of the stream was $5.43 \pm 0.43$

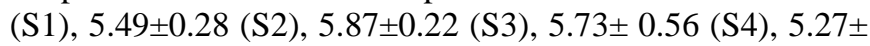
0.55 (S5), 5.74 \pm 0.16 (S6), $5.82 \pm 0.29$ (S7) and 5.45 0.58 (S8) respectively. All the $\mathrm{pH}$ values were slightly acidic and below the recommended limits $(6.5-8.5)$ by both WHO and NESREA. Values for TDS, EC, TSS, DO, COD, BOD 5 , and Nitrate at all the sampling stations were found to be within $\mathrm{WHO}$ and NESREA permissible limits. Phosphate level $(\mathrm{mg} / \mathrm{L})$ were $5.07 \pm 1.42$ (S1), 5.03 $\pm 1.92(\mathrm{~S} 2), 11.7 \pm 3.87$ (S3), 10.02 \pm 5.14

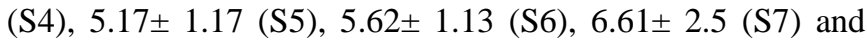
$14.45 \pm 11.1$ (S8) respectively. These values were higher than the limit $(2-5 \mathrm{mg} / \mathrm{L})$ recommended by NESREA. Total coliform counts (MPN/100mL) ranged from $1.42 \times 10^{4}(\mathrm{~S} 1)$ to $497 \times 10^{4}(\mathrm{~S} 8)$ while that of $E$. coli ranged from $1.34 \times 10^{4}(\mathrm{~S} 1)$ to $3.8 \times 10^{4}(\mathrm{~S} 8)$. Correlation matrix (Table 5) shows that a significant positive correlation existed between $\mathrm{BOD}_{5}$ and other parameters such as COD $(r=0.97, \mathrm{P}<0.01), \mathrm{EC}(\mathrm{r}=0.71$, $\mathrm{P}<0.05)$, TDS $(\mathrm{r}=0.75, \mathrm{P}<0.05)$, TCC $(\mathrm{r}=0.89, \mathrm{P}<0.05)$, and E. coli $(\mathrm{r}=0.86, \mathrm{P}<0.05)$. Positive correlation also exists between EC and TDS ( $\mathrm{r}=0.98, \mathrm{P}<0.01)$, Nitrate and Total coliforms $(\mathrm{r}=0.82, \mathrm{P}<0.05)$, E. coli $(\mathrm{r}=0.91, \mathrm{P}<0.01)$.

Table 4. Characteristics of Yemetu stream

\begin{tabular}{|c|c|c|c|c|c|c|c|c|c|c|c|}
\hline & & \multicolumn{8}{|c|}{ Sampling stations } & \multirow[b]{2}{*}{$\begin{array}{c}\text { NESREA } \\
\text { Limit } \\
\end{array}$} & \multirow[b]{2}{*}{$\begin{array}{l}\text { WHO } \\
\text { Limit } \\
\end{array}$} \\
\hline Parameters & Unit & S1 & $\mathbf{S 2}$ & $\mathbf{S 3}$ & S4 & S5 & S6 & S7 & S8 & & \\
\hline pH & & $5.4 \pm 0.40$ & $\begin{array}{c}5.49 \pm \\
0.28\end{array}$ & $\begin{array}{c}5.87 \pm \\
0.22\end{array}$ & $\begin{array}{c}5.73 \pm \\
0.56\end{array}$ & $\begin{array}{c}5.27 \pm \\
0.55\end{array}$ & $\begin{array}{c}5.74 \pm \\
0.16\end{array}$ & $\begin{array}{c}5.82 \pm \\
0.29\end{array}$ & $5.45 \pm 0.58$ & $6-9$ & $\begin{array}{l}6.5- \\
8.5\end{array}$ \\
\hline EC & $\mu \mathrm{S} / \mathrm{cm}$ & $12.22 \pm 0.55$ & $\begin{array}{c}11.50 \pm \\
1.17\end{array}$ & $\begin{array}{c}12.61 \pm \\
2.39\end{array}$ & $\begin{array}{c}12.50 \pm \\
2.53\end{array}$ & $\begin{array}{c}11.49 \pm \\
1.46\end{array}$ & $\begin{array}{c}11.94 \pm \\
1.30\end{array}$ & $\begin{array}{c}12.87 \pm \\
0.94\end{array}$ & $12.62 \pm 0.93$ & - & 400 \\
\hline DO & $\mathrm{mg} / \mathrm{l}$ & $1.76 \pm 0.97$ & $\begin{array}{c}1.93 \pm \\
1.13\end{array}$ & $\begin{array}{c}2.07 \pm \\
0.73\end{array}$ & $\begin{array}{c}1.67 \pm \\
0.46\end{array}$ & $\begin{array}{c}2.45 \pm \\
1.23\end{array}$ & $\begin{array}{c}1.75 \pm \\
0.49\end{array}$ & $\begin{array}{c}1.79 \pm \\
1.17\end{array}$ & $1.26 \pm 0.35$ & - & 7.5 \\
\hline BOD & $\mathrm{mg} / \mathrm{l}$ & $7.99 \pm 1.32$ & $\begin{array}{l}7.72 \pm \\
2.42\end{array}$ & $\begin{array}{c}8.78 \pm \\
1.52\end{array}$ & $\begin{array}{c}8.63 \pm \\
1.22\end{array}$ & $\begin{array}{c}8.32 \pm \\
1.71\end{array}$ & $\begin{array}{c}8.48 \pm \\
1.54\end{array}$ & $\begin{array}{c}8.68 \pm \\
1.81\end{array}$ & $10.59 \pm 2.13$ & 30 & 40 \\
\hline COD & $\mathrm{mg} / \mathrm{l}$ & $\begin{array}{c}20.33 \pm \\
3.27\end{array}$ & $\begin{array}{c}19.71 \pm \\
5.57\end{array}$ & $\begin{array}{c}22.10 \pm \\
3.81\end{array}$ & $\begin{array}{c}22.0 \pm \\
2.95\end{array}$ & $\begin{array}{c}21.46 \pm \\
4.13\end{array}$ & $\begin{array}{c}22.65 \pm \\
4.34\end{array}$ & $\begin{array}{c}22.15 \pm \\
4.79\end{array}$ & $26.59 \pm 4.82$ & 60 & 80 \\
\hline TDS & $\mathrm{mg} / \mathrm{l}$ & $7.70 \pm 0.37$ & $\begin{array}{c}7.41 \pm \\
0.75\end{array}$ & $\begin{array}{c}8.81 \pm \\
1.37\end{array}$ & $\begin{array}{c}8.92 \pm \\
1.52\end{array}$ & $\begin{array}{c}7.89 \pm \\
0.98\end{array}$ & $\begin{array}{c}8.20 \pm \\
0.81\end{array}$ & $\begin{array}{c}8.56 \pm \\
0.52\end{array}$ & $8.42 \pm 0.58$ & 500 & 500 \\
\hline TSS & $\mathrm{mg} / \mathrm{l}$ & $5.71 \pm 0.97$ & $\begin{array}{c}11.36 \pm \\
5.17\end{array}$ & $\begin{array}{l}7.34 \pm \\
1.05\end{array}$ & $\begin{array}{c}11.31 \pm \\
4.99\end{array}$ & $\begin{array}{c}10.54 \pm \\
3.67\end{array}$ & $\begin{array}{c}8.54 \pm \\
3.41\end{array}$ & $\begin{array}{l}9.96 \pm \\
2.85\end{array}$ & $9.20 \pm 4.27$ & 30 & - \\
\hline Nitrate & $\mathrm{mg} / \mathrm{l}$ & $1.5 \pm 0.23$ & $\begin{array}{c}1.52 \pm \\
0.15\end{array}$ & $\begin{array}{c}1.51 \pm \\
0.51\end{array}$ & $\begin{array}{c}1.55 \pm \\
0.32\end{array}$ & $\begin{array}{c}1.56 \pm \\
0.73\end{array}$ & $\begin{array}{c}1.53 \pm \\
0.62\end{array}$ & $\begin{array}{c}1.58 \pm \\
0.88\end{array}$ & $1.59 \pm 0.73$ & 45 & 50 \\
\hline Phosphate & $\mathrm{mg} / \mathrm{l}$ & $5.07 \pm 1.42$ & $\begin{array}{c}5.03 \pm \\
1.92\end{array}$ & $\begin{array}{c}11.65 \pm \\
3.87\end{array}$ & $\begin{array}{c}10.02 \pm \\
5.14\end{array}$ & $\begin{array}{c}5.17 \pm \\
1.17\end{array}$ & $\begin{array}{c}5.62 \pm \\
1.13\end{array}$ & $\begin{array}{l}6.61 \pm \\
2.5\end{array}$ & $14.45 \pm 11.17$ & $2-5$ & 0.1 \\
\hline $\begin{array}{c}\text { Total } \\
\text { Coliforms }\end{array}$ & MPN/100ml & 142 & 149 & 193 & 290 & 285 & 248 & 441 & 328 & & 10 \\
\hline E. coli & MPN/100ml & 134 & 142 & 173 & 197 & 238 & 233 & 360 & 273 & 0 & 0 \\
\hline
\end{tabular}

Note: All parameters are expressed in arithmetic mean except Total coliform and E. coli that are expressed in geometric mean 
Table 5. Correlates of pollution load of Yemetu Stream

\begin{tabular}{|c|c|c|c|c|c|c|c|c|c|c|c|}
\hline Parameter & pH & EC & DO & BOD5 & COD & TDS & TSS & $\mathrm{NO}_{3}$ & $\mathrm{PO}_{4}{ }^{2-}$ & TCC & E.Coli \\
\hline pH & 1.00 & & & & & & & & & & \\
\hline EC & 0.63 & 1.00 & & & & & & & & & \\
\hline DO & -1.80 & -0.56 & 1.00 & & & & & & & & \\
\hline BOD5 $_{5}$ & -0.57 & $0.71 *$ & -1.34 & 1.00 & & & & & & & \\
\hline COD & 0.43 & 0.59 & -0.16 & $0.97 *$ & 1.00 & & & & & & \\
\hline TDS & 0.63 & $0.98 * *$ & -0.55 & $0.75^{*}$ & 0.65 & 1.00 & & & & & \\
\hline TSS & $-0.71 *$ & -0.26 & 0.11 & 0.09 & 0.17 & -0.11 & 1.00 & & & & \\
\hline $\mathrm{NO}_{3}$ & 0.21 & 0.40 & -0.30 & $0.73^{*}$ & $0.76^{*}$ & 0.41 & 0.46 & 1.00 & & & \\
\hline $\mathrm{PO}_{4}{ }^{2-}$ & 0.25 & 0.63 & -0.54 & 0.16 & 0.11 & 0.60 & -0.40 & 0.15 & 1.00 & & \\
\hline TCC & 0.28 & 0.55 & -0.22 & $0.89 *$ & $0.93 * *$ & 0.64 & 0.35 & $0.82 *$ & 0.23 & 1.00 & \\
\hline E.coli & 0.24 & 0.47 & -0.19 & $0.86^{*}$ & $0.91 * *$ & 0.53 & 0.28 & $0.91 * *$ & 0.15 & $0.97 * *$ & 1.00 \\
\hline
\end{tabular}

\subsection{Water quality index}

Table 6 shows the Water Quality Index (WQI) of Yemetu stream based on sampling stations where water samples were collected. From the table, it was revealed that the first sampling station S1 was found to have the least value of WQI of 227 compared to other sampling stations while sampling station seven (S7) recorded the highest value of 668 . Figure 2 shows the WQI of the stream based on the four weeks of sample collection. The figure shows that the WQI for the first two sampling stations fell within the range of very poor water throughout the four weeks of sampling collection while the rest of the sampling stations (S3-S8) for the four weeks fell within the range of water not suitable for drinking.

Table 6. Water Quality Indices of Yemetu stream based on sampling station

\begin{tabular}{ccc}
\hline Sampling Location & WQI & Water quality classification \\
\hline S1 & 227 & Very poor water \\
S2 & 239 & Very poor water \\
S3 & 304 & Water unsuitable for drinking \\
S4 & 446 & Water unsuitable for drinking \\
S5 & 439 & Water unsuitable for drinking \\
S6 & 384 & Water unsuitable for drinking \\
S7 & 668 & Water unsuitable for drinking \\
S8 & 502 & Water unsuitable for drinking \\
\hline
\end{tabular}

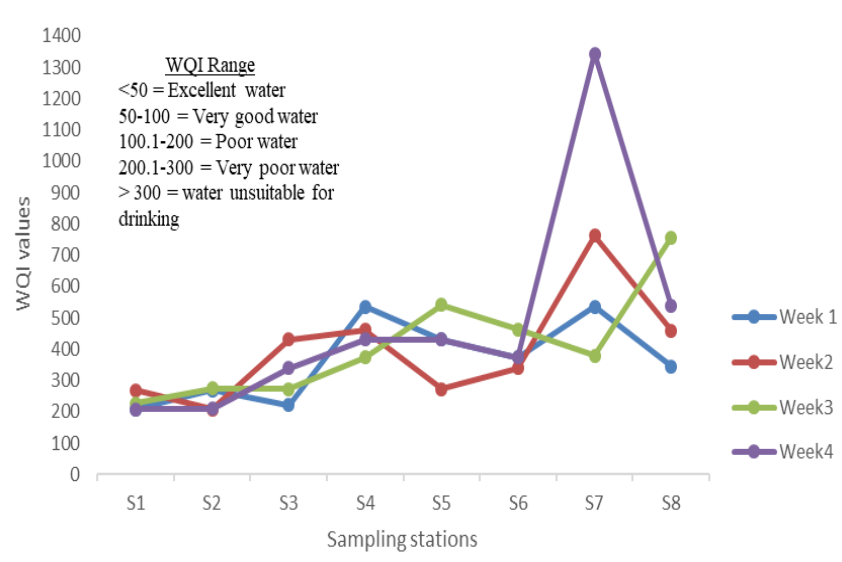

Figure 2. Water quality index of Yemetu stream across the four weeks of sample collection

\subsection{Essential parameters in the assessment of pollution load and tropic status of Yemetu stream}

The mean values of surface water quality parameters in the eight stations over 4 weeks were used to determine the essential parameters using principal component analysis (PCA) as seen in Table 7. The PCA factors are the main factors and express $83.549 \%$ of variance or changes as presented in Table 7 . The table revealed that the most important factors justifying water quality changes were $E$. coli, Total Coliforms, phosphate, and $\mathrm{BOD}_{5}$. These are the first factor that shows $59.394 \%$ of the variance. The second factor shows $24.154 \%$ of change and includes COD, DO, and $\mathrm{pH}$.

Table 7. Rotation component matrix for physicochemical and bacteriological parameters in the Yemetu stream

\begin{tabular}{ccc}
\hline \multirow{2}{*}{ Parameters } & \multicolumn{2}{c}{ Component } \\
\cline { 2 - 3 } & 1 & 2 \\
\hline E. coli & $\mathbf{0 . 9 4 3}$ & -0.029 \\
Total coliforms & $\mathbf{0 . 9 0 7}$ & 0.081 \\
Nitrate & 0.269 & -0.057 \\
Phosphate & $\mathbf{0 . 8 0 2}$ & -0.050 \\
COD & 0.169 & $\mathbf{0 . 8 8 8}$ \\
BOD5 & $\mathbf{0 . 7 1 3}$ & 0.149 \\
DO & -0.287 & $\mathbf{0 . 7 2 8}$ \\
Temperature & -0.136 & 0.568 \\
pH & 0.034 & $\mathbf{0 . 8 9 6}$ \\
TSS & 0.271 & 0.324 \\
\% of variance explained & 59.394 & 24.154 \\
\% of cumulative & 59.394 & 83.549 \\
\hline
\end{tabular}

Furthermore, all the eight sampling stations were placed in three clusters during the cluster analysis as depicted in Figure 3. In the Figure, three clusters were extracted: The first cluster comprised stations 1 and 2, the second cluster contained stations 3, 4, 5 and 6 while the third cluster incorporated stations 8. In cluster 1(i.e. stations 1 and 2) $\mathrm{pH}$, phosphate, total coliforms and $E$. coli of the two sampling stations were similar. The $\mathrm{pH}$ was extremely lower, phosphate, Total coliform, and E. coli showed that the water was grossly polluted. Other parameters were within the recommended standards. In cluster 2, (Station 3, 4, 5 and 6) phosphate, total coliforms and $E$. coli of the two sampling stations were extremely higher than the values obtained in cluster 1 . 
Furthermore, Cluster 3 revealed that the sampling station 8 had phosphate, total coliforms and E. coli values that were higher. Other parameters were within the recommended limits by WHO and NESREA.

Trophic status evaluation of the stream was carried out according to Wetzel [24]. Phosphate concentrations (mg/L) of all the eight sampling points were higher than 0.1 , clearly indicating hypereutrophic status as depicted in Figure 4. Furthermore, phosphate concentrations were extremely high in sampling points 3,4 and 8 respectively.

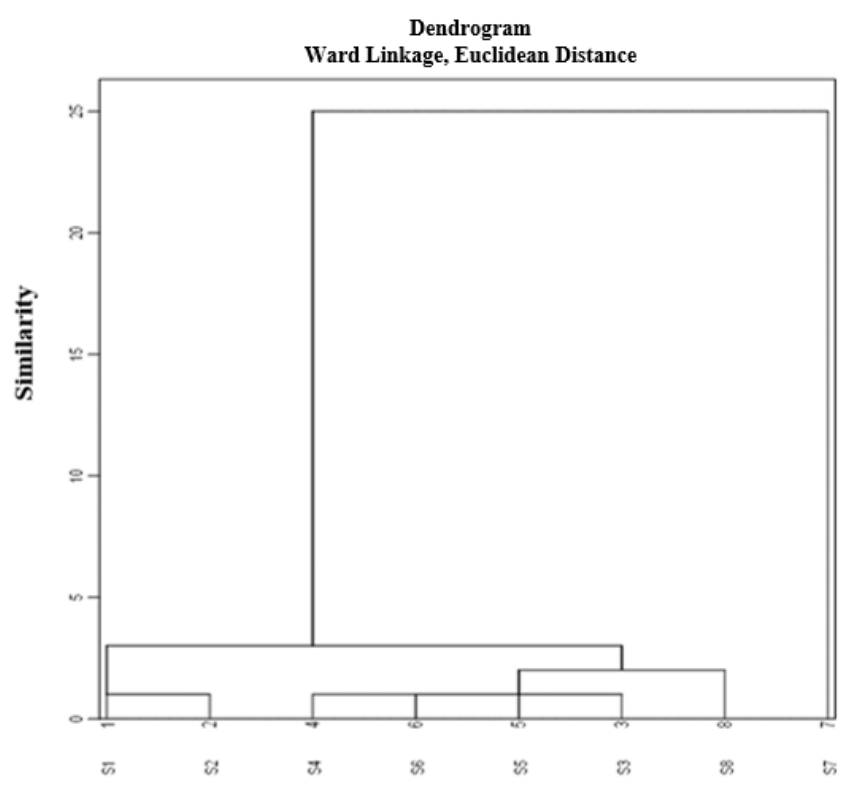

Figure 3. Clustering of stations in the study area using clustering analysis

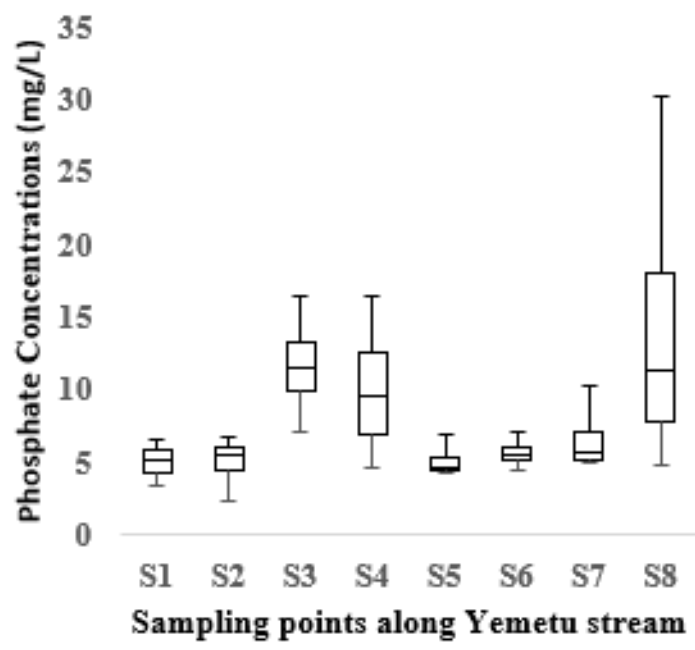

Figure 4. Trophic status of the sampling points along Yemetu stream

\section{DISCUSSION}

This study revealed that the $\mathrm{pH}$ values of samples observed in all sampling locations were below the permissible limit of 6-9 set by NESREA [25] which indicates that all the water samples were acidic. The reason for the acidic nature of the water samples observed in all sampling locations might be a result of refuse around the stream which may contain acidic substances. The study does not concur with a $\mathrm{pH}$ range of 6.017.27 reported by Eze [26]. This may be as a result of the difference in location and practice of refuse disposal in the area. Stephanie [27] indicated in her study that acidic soils and rocks such as basalt, granite, and sandstone could also be a contributory factor to lower $\mathrm{pH}$ values in water. The study reported that parameters such as TDS, TSS, EC, BOD, COD, DO and Nitrate in all sampling stations fell within the permissible limits by WHO and NESREA. Several studies have reported similar findings [28-33].

Data from this study revealed that $\mathrm{BOD}_{5}$ had the most correlation with other parameters such as COD, EC, TDS, TCC, and $E$. coli and a positive correlation also exists between Electrical Conductivity and TDS, Nitrate and Total coliforms, and E. coli. Biochemical Oxygen Demand and COD have been reported as important parameters that indicate contamination with organic wastes [33]. The BOD is one of the parameters required to assess the pollution of surface and groundwater where contamination occurred due to disposal of domestic and industrial effluents [34]

Our study also revealed that values obtained from the Water Quality Index ranged from 227 in S1 to 668 in S7. The range shows that the stream was in a very poor state and water unsuitable for domestic purposes. This finding concurs with the report of a study by Ravikumar and Mehmood [34] where WQI classified Mallathahalli lake water as poor water. This assessment has revealed that the stream at all sampling stations was heavily polluted and is unfit for human consumption and other domestic purposes. Sampling station 7 had the highest level of pollution. The extreme level of pollution may be due to various anthropogenic activities such as direct discharge of wastewater from surrounding households into the stream and deposition of various solid waste into the stream. Similar study by Fathi et al [35] reported that the WQI of the stream in the study increased from upstream to downstream.

This study revealed that the phosphate concentration of water samples from the eight sampling stations were higher compared to the limit $(2-5 \mathrm{mg} / \mathrm{L})$ recommended by NESREA [25]. This does not support the finding of the study study by Ishola et al [36] where the highest value of phosphate reported was $0.13 \mathrm{mg} / \mathrm{L}$. A high concentration of phosphate could be attributed to the discharge of detergents into the stream by the surrounding houses at various points. Furthermore, the trophic status of the Yemetu stream was classified as hypereutrophic during the sampling period. Phosphates are chemicals containing the element phosphorus, and in excess quantities, phosphorus can lead to water quality problems such as eutrophication and harmful algal growth [37]. Sources of phosphorous in surface water have been identified as human excreta, and some industrial and trade effluents [34]. Other sources may be as a result of domestic waste, detergent and agricultural runoff containing fertilizer [38].

It was found that the sampling station 1 (S1), a station at an upstream community had the least number of coliform organisms compared to other stations. This sampling station is located in a low residential area where practices such as dumping of refuse and discharge of untreated sewage were minimal compared to other stations. However, sampling station 7 (S7) recorded the highest number of coliforms which could be as a result of increased practice of stream defecation and massive dumping of refuse into the stream. The number of E. coli organisms in all sampling stations was extremely above the permissible limit. Studies have reported a high count of coliforms in surface water [39-41]. The presence of E. coli in 
all the water samples is evidence of faecal contamination from human and warm-blooded animals which may indicate the presence of pathogenic organisms.

Data from this study revealed that the PCA factors such as E. coli, Total Coliform Count, phosphate, and BOD were the main factors responsible for the pollution load of Yemetu stream. Other parameters identified were COD, DO, and $\mathrm{pH}$. This finding is similar to a previous study which reported that principal component analysis (PCA) analysis of more important parameters were in factor 1 while the less important ones in the second factor [35]

Furthermore, all the cluster identified through cluster analysis (CA) shows that the stream was grossly polluted. This might have resulted from the high occurrence of phosphate, total coliform and E. coli, BOD and $\mathrm{pH}$ values of these sampling stations than the recommended limits by WHO and NESREA. Previous studies have reported similar findings using multivariate statistical methods such as PCA and cluster analysis (CA) to identify potential pollutants in surface water $[35,42-45]$.

\section{CONCLUSION}

The findings of this study have revealed that almost all the physico-chemical parameters were within the permissible limits with the exception of $\mathrm{pH}$ and phosphate that were above the limits. The bacteriological parameters (Total coliform and E. coli) were found to exceed the permissible limits in all sampling stations which indicate that the stream water was rich in microbes that could be detrimental to human health when consumed. The BOD, though within the permissible limit had the most significant correlation with other parameters (COD, EC, TDS, Total Coliform, and E. coli) which indicate that the BOD of the stream water must be strictly monitored in order to prevent subsequent pollution. The WQI computation classified the stream water quality as being very poor and unsuitable for drinking. the Principal Component Analysis factors such as E. coli, Total Coliform Count, phosphate, and BOD were the main factors responsible for the pollution load of the Yemetu stream. Other parameters identified were COD, $\mathrm{DO}$, and $\mathrm{pH}$. Furthermore, all the clusters identified through cluster analysis (CA) shows that the stream was grossly polluted. The study recommends prompt monitoring of water quality of Yemetu stream (most especially the bacteriological characteristics and BOD) through the control of various anthropogenic activities around the stream by the appropriate authorities.

\section{ACKNOWLEDGEMENT}

The authors wish to thank and acknowledge the contributions of the landlords' association of the community.

\section{REFERENCES}

[1] Allan, J.D. (1995). Stream Ecology- Structure and Function of Running Waters. 1st ed. Chapman \& Hall. xii, 388.

[2] Tyagi, S., Sharma, B., Singh, P., Dobhal, R. (2013). Water quality assessment in terms of water quality index. American Journal of Water Resources, 1(3): 34-38. https://doi.org/10.12691/ajwr-1-3-3

[3] May, A.M., Mutasem, E., Mark, D.S., Lester, J.N. (2006). Factors influencing development of management strategies for the Abou Ali River in Lebanon II: Seasonal and annual variation. Science of the Total Environment, 362(1-3): $31-41$. https://doi.org/10.1016/j.scitotenv.2005.09.079

[4] Wang, X., Lu, Y., Han, J., He, G., Wang, T. (2007). Identification of anthropogenic influences on water quality of rivers in Taihu watershed. Journal of Environmental Sciences. 19(4): 475-481. https://doi.org/10.1016/S1001-0742(07)60080-1

[5] Cornish, G., Mensah, A. (1999). Water Quality and Periurban Irrigation. Report OD/TN95 HR Wallingford, Wallingford, UK.

[6] Li, R., Dong, M., Zhao, Y., Zhang, L., Cui, Q., He, W. (2007), Assessment of Water Quality and Identification of Pollution Sources of Plateau Lakes in Yunnan (China), Journal of Environmental Quality 36(1): 291-297. https://doi.org/10.2134/jeq2006.0165

[7] Etim, E.E., Odoh, R., Itodo, A.U., Umoh, S.D, Lawal, U. (2013). Water quality index for the assessment of water quality from different sources in the Niger Delta region of Nigeria. Frontiers in Science, 3(3): 89-95. https://doi.org/10.5923/j.fs.20130303.02

[8] Miller, W.W., Joung, H.M., Mahannah, C.N., Garrett, J.R. (1986). Identification of water quality differences in nevada through index application. Journal of Environmental Quality, 15(3): 265-272. https://doi.org/10.2134/jeq1986.0047242500150003001 $2 \mathrm{x}$

[9] Samantray, P., Mishra, B.K., Panda, C.R., Rout, S.P. (2009). Assessment of water quality index in Mahanadi and Atharabanki Rivers and Taldanda Canal in Paradip area, India. Journal of Human Ecology, 26(3): 153-161. https://doi.org/10.1080/09709274.2009.11906177

[10] Sharma, D., Kansal, A. (2011). Water quality analysis of River Yamuna using water quality index in the national capital territory, India (2000-2009). Applied Water Science, 1: 147-157. https://doi.org/10.1007/s13201011-0011-4

[11] Alam, M., Pathak, J.K. (2010). Rapid assessment of water quality index of Ramganga River, Western Uttar Pradesh (India) using a computer programme. Nature and Science, 8(11): 1-8.

[12] Asuquo, J.E., Etim, E.E. (2012). Water quality index for assessment of borehole water quality in Uyo metropolis, Akwa Ibom state, Nigeria. International Journal of Modern $\quad$ Chemistry, 3(3): $\quad 89-95$. https://doi.org/10.5923/j.fs.20130303.02

[13] Hulya, B. (2009) Utilization of the water quality index method as a classification tool. Environmental Monitoring and Assessment, 167: 115-124. https://doi.org/10.1007/s10661-009-1035-1

[14] Jagadeeswari, P.B., Ramesh, K. (2012). Water quality index for assessment of water quality in south Chennai coastal aquifer, Tamil Nadu, India. International Journal of Chem. Tech Research, 4(4): 1582-1588.

[15] Osibanjo, O., Daso, P.A., Gbadebo M.A. (2011). The impact of industries on surface water quality of River Ona and River Alaro in Oluyole Industrial Estate, Ibadan, Nigeria. African Journal of Biotechnology, 10(4): 696702 .

[16] Arimoro, F.O. (2009). Impact of Rubber Effluent 
Discharges on the water quality and macroinvertebrate community assemblages in a forest stream in the Niger Delta, Nigeria. Chemosphere, 77(3): 440-449. https://doi.org/10.1016/j.chemosphere.2009.06.031

[17] Nnamani, E.V., Akpagu, F.C., Eze, C.G.I. (2015). The analysis of selected physico-chemical parameters of water (a case study of ISU and Calabar Rivers in Ebonyi State, Nigeria). IOSR Journal of Applied Chemistry (IOSR-JAC), 8(1): 21-25.

[18] Ani, C., Okogwu, O.I., Nwonumara, G.N., Nwani, C.D., Nwiniyimagu, A.J. (2016). Evaluation of physicochemical parameters of selected rivers in Ebonyi State, Southeast, Nigeria. Greener Journal of Biological Sciences, 6(2): 34-41. https://doi.org/10.15580/GJBS.2016.2.020216030

[19] Amah-Jerry, E.B., Anyanwu, E.D., Avoaja, D.A. (2017). Anthropogenic impacts on the water quality of Aba River, South, East Nigeria. Ethiopian Journal of Environmental Studies \& Management, 10(3): 299-314. https://dx.doi.org/10.4314/ejesm.v10i3.3

[20] Oloruntoba, E.O., Amubieya, O.E., Adejumo, M., Sridhar, M.K.C. (2019). Status of sanitation facilities and factors influencing faecal disposal practices in selected low-income communities in Ibadan, Nigeria. Journal of Environment Pollution and Human Health, 7(2): 62-72 https://doi.org/10.12691/jephh-7-2-2

[21] American Public Health Association (APHA) (2005). Standard Methods for Examination of Water and Waste Water $21^{\text {st }}$ Edition, APHA, Washington D.C.

[22] Mohamad, Najib Ibrahim. (2019). Assessing groundwater quality for drinking purpose in Jordan: Application of water quality index. Journal of Ecological Engineering, 20(3): 101-111. https://doi.org/10.12911/22998993/99740

[23] Sahu, P., Sikdar, P.K. (2008). Hydrochemical framework of the Aquifer in and around East Kolkata Wetlands, West Bengal, India. Environmental Geology, 55: 823835. http://dx.doi.org/10.1007/s00254-007-1034-x

[24] Wetzel, R.G. (1975). Limnology. W.B. Saunders Co., Philadelphia, London, and Toronto.

[25] NESREA. (2009). National Environmental Standards and Regulation Enforcement Agency (NESREA) Regulations. Volume 96, Number 65, the Federal Government Printer, Abuja, Nigeria.

[26] Eze, S.O., Chigbu, G.C. (2015). physical, chemical and microbiological parameters of Iyi Okai Stream in Abiriba, Ohafia local government area, Abia State, Nigeria. European Journal of Pure and Applied Chemistry, 2(1). https://doi.org/10.13140/RG.2.1.2339.5447

[27] Stephanie, M. (1998). Water quality parameters and indicators; Namoi catchment management authority. https://www.namoi.cma.nsw.gov.au , accessed on Dec 9, 2019.

[28] Shyamala, R., Shanthi, M., Lalitha, P. (2009). Physicochemical analysis of bore well water samples of Telungupalayam Area in Coimbatore District, Tamilnadu, India. Elect. J Chem. 5: 924-929. https://doi.org/10.1155/2008/152383

[29] Navneet, K., Sinthan, D.K. (2010). Drinking water quality management through correlation studies among various physicochemical parameters: A case study. International Journal of Environmental Sciences, 1(2): 253-259.

[30] Egwuonwu, C.C., Uzoije, A.P., Okafor, V.C., Ezeanya
N.C, Nwachukwu, M.U. (2012). Evaluation of the effects of industrial wastewater discharge on surface water (a case study of Nigeria Breweries Plc Enugu). Greener Journal of Physical Sciences, 2(3): 56-63.

[31] Dimowo, B.O. (2013). Assessment of some Physicochemical Parameters of River Ogun (Abeokuta, Ogun State, Southwestern Nigeria) in comparison with national and international standard. International Journal of $\quad$ Aquaculture, 3(15): 79-84. https://doi.org/10.5376/ija.2013.03.0015

[32] Monney, I., Odai, S.N., Buamah, R., Awuah, E., Nyenje, P.M. (2013). Environmental impacts of wastewater from urban slums: Case study-Old Fadama, Accra. International Journal of Development and Sustainability, 2(2): 711-728

[33] Siraj, S., Yousuf, A.R., Bhat, F.A., Parveen, N. (2010). The ecology of macrozoobenthos in Shallabugh wetland of Kashmir Himalaya, India. Eco Nat Environ, 2(5): 8491.

[34] Ravikumar, P., Mehmood, M.A., Somashekar, R.K. (2013). Water quality index to determine the surface water quality of Sankey tank and Mallathahalli Lake, Bangalore urban district, Karnataka, India. Appl Water Sci., 3: 247-261. https://doi.org/10.1007/s13201-0130077-2

[35] Fathi, E., Zamani-Ahmadmahmoodi, R., Zare-Bidaki, R. (2018). Water quality evaluation using water quality index and multivariate methods, Beheshtabad River, Iran. Applied Water Science, 8: 210. https://doi.org/10.1007/s13201-018-0859-7

[36] Ishola, S.A., Makinde, V., Okeyode, I.C., Akinboro, F.G., Ayedun, H., Alatise, O.O. (2016). Assessment of pollution hazards of groundwater resource in Abeokuta North Local Government Area, Ogun State, Southwestern Nigeria. Journal of National Science Engineering \& Technology, 15(1): 42-56.

[37] Helmut, K., Helmut, R., Lukas, E. (2011). Phosphorus in Water Quality and Waste Management, Integrated Waste Management - Volume II, Sunil Kumar, IntechOpen. https://doi.org/10.5772/18482

[38] Gopalkrushna, M.H. (2011). Determination of Physicochemical parameters of surface water samples in and around Akot City. International Journal of Research in Chemistry and Environment, 1(2): 183-187.

[39] Gu, Q., Deng, J., Wang, K., Lin, Y., Li, J., Gan, M., Ma, L., Hong, Y. (2014). Identification and assessment of potential water quality impact factors for drinking-water reservoirs. International Journal of Environmental Research and Public Health, 11(6): 6069-6084. https://doi.org/10.3390/ijerph110606069

[40] Obioma, A., Chikanka, A.T., Loveth, N.W. (2017). Evaluation of bacteriological quality of surface, well, borehole and river water in Khana local government area of Rivers State, Niger Delta. Ann Clin Lab Res., 5(3): 183. https://doi.org/10.21767/2386-5180.1000183

[41] Onyango, A.E., Okoth, M.W., Kunyanga, C.N., Aliwan, B.O. (2018). Microbiological quality and contamination level of water sources in Isiolo County in Kenya. Journal of Environmental and Public Health, 2018: 1-10. https://doi.org/10.1155/2018/2139867

[42] Massoud, M.A. (2012). Assessment of water quality along a recreational section of the Damour River in Lebanon using the water quality index. Environ Monit Assess, 184: 4151-416. https://doi.org/10.1007/s10661- 
011-2251-Z

[43] Lin, Y., Han, P., Huang, Y., Yuan, G.L., Guo, X., Li, J. (2017). Source identification of potentially hazardous elements and their relationships with soil properties in agricultural soil of the Pinggu district of Beijing, China: Multivariate statistical analysis and redundancy analysis. Journal of Geochemical Exploration, 173: 110-118. https://doi.org/10.1016/j.gexplo.2016.12.006

[44] Misaghi, F., Delgosha, F., Razzaghmanesh, M., Myers, B. (2017). Introducing a water quality index for assessing water for irrigation purposes: A case study of the Ghezel Ozan River. Science of Total Environment, 589: 107-116. https://doi.org/10.1016/j.scitotenv.2017.02.226

[45] Zamani-Ahmadmahmoodi, R., Jafari, A., Alibeygi-Beni, H. (2017). Potential ecological risk assessment, enrichment, geoaccumulation, and source identification of metals in the surface sediments of Choghakhor Wetland, Iran. Environmental Earth Sciences, 76(11): 398. https://doi.org/10.1007/s12665-017-6718-2 